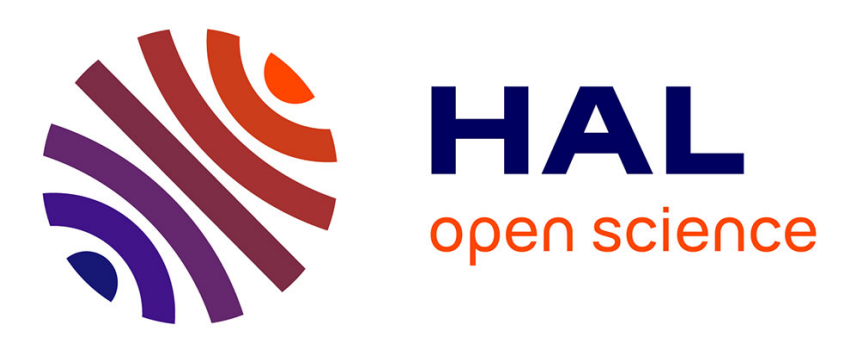

\title{
Influence of estuarine hypoxia on feeding and sound production by two sympatric pipefish species (Syngnathidae)
}

Jennifer L. Ripley, Christy M. Foran

\section{- To cite this version:}

Jennifer L. Ripley, Christy M. Foran. Influence of estuarine hypoxia on feeding and sound production by two sympatric pipefish species (Syngnathidae). Marine Environmental Research, 2007, 63 (4), pp.350. 10.1016/j.marenvres.2006.10.003 . hal-00562961

\section{HAL Id: hal-00562961 https://hal.science/hal-00562961}

Submitted on 4 Feb 2011

HAL is a multi-disciplinary open access archive for the deposit and dissemination of scientific research documents, whether they are published or not. The documents may come from teaching and research institutions in France or abroad, or from public or private research centers.
L'archive ouverte pluridisciplinaire HAL, est destinée au dépôt et à la diffusion de documents scientifiques de niveau recherche, publiés ou non, émanant des établissements d'enseignement et de recherche français ou étrangers, des laboratoires publics ou privés. 


\section{Accepted Manuscript}

Influence of estuarine hypoxia on feeding and sound production by two sympatric pipefish species (Syngnathidae)

Jennifer L. Ripley, Christy M. Foran

PII:

S0141-1136(06)00192-9

DOI:

10.1016/j.marenvres.2006.10.003

Reference:

MERE 3073

To appear in:

Marine Environmental Research

Received Date: $\quad 5$ February 2005

Revised Date: $\quad 12$ October 2006

Accepted Date: $\quad 13$ October 2006

Please cite this article as: Ripley, J.L., Foran, C.M., Influence of estuarine hypoxia on feeding and sound production by two sympatric pipefish species (Syngnathidae), Marine Environmental Research (2006), doi: 10.1016/ j.marenvres.2006.10.003

This is a PDF file of an unedited manuscript that has been accepted for publication. As a service to our customers we are providing this early version of the manuscript. The manuscript will undergo copyediting, typesetting, and review of the resulting proof before it is published in its final form. Please note that during the production process errors may be discovered which could affect the content, and all legal disclaimers that apply to the journal pertain. 
Influence of estuarine hypoxia on feeding and sound production by two sympatric pipefish species (Syngnathidae)

Jennifer L. Ripley * , Christy M. Foran

West Virginia University, Biology Department, P.O. Box 6057, Morgantown, WV 26506, USA

* Corresponding author. Tel: 304 293-5201. Fax: 304 293-6363.

E-mail addresses: jripley@mix.wvu.edu (J. Ripley), cmforan@mail.wvu.edu (C. Foran) 


\begin{abstract}
This research utilizes the acoustic behavior of two sympatric pipefish species to assess the impact of hypoxia on feeding. We collected northern, Syngnathus fuscus, and dusky pipefishes, Syngnathus floridae, from the relatively pristine Chincoteague Bay, Virginia, USA and audiovisually recorded behavior in the laboratory of fish held in normoxic $\left(>5 \mathrm{mg} / \mathrm{L} \mathrm{O}_{2}\right)$ and hypoxic (2 and $1 \mathrm{mg} / \mathrm{L} \mathrm{O}_{2}$ ) conditions. Both species produced high frequency $(\sim 0.9-1.4 \mathrm{kHz})$, short duration (3 - $22 \mathrm{msec}$ ) clicks. Feeding strikes were significantly correlated with both wet weight of ingested food and click production. Thus, sound production serves as an accurate measure of feeding activity. In hypoxic conditions, reduced food intake corresponded with decreased sound production. Significant declines in both behaviors were evident after 1 day and continued as long as hypoxic conditions were maintained. Interspecific differences in sensitivity were detected. Specifically, S. floridae showed a tendency to perform head snaps at the surface. Syngnathus fuscus exhibited a breakdown in the coupling of sound production with food intake in $2 \mathrm{mg} / \mathrm{L} \mathrm{O}_{2}$ with clicks produced in other contexts, particularly choking and food expulsion. Reductions in feeding will ultimately impact growth, health, and eventually reproduction as resources are devoted to survival instead of gamete production and courtship. This work suggests acoustic monitoring of field sites with adverse environmental conditions may reflect changes in feeding behavior in addition to population dispersal.
\end{abstract}

Keywords: Hypoxia; Feeding; Sound Production; Syngnathus fuscus; Syngnathus floridae 


\section{Introduction}

No environmental factor of such ecological importance to coastal and estuarine systems has changed as rapidly as dissolved oxygen (DO; Diaz, 2001; Goldberg, 1995; Nixon, 1990). The Chesapeake Bay is the largest and most productive estuary in the United States, yeilding more than $70 \%$ of the nation's blue crab catch (Wang, Batiuk, Linker \& Shenk, 2001). Hypoxia, or DO concentrations below $2 \mathrm{mg} / \mathrm{L}$, dominates the summer months with conditions declining to anoxic levels (Diaz, 2001; Diaz \& Rosenberg, 1995; Nixon, 1995; Breitburg, 1990; Holland, Shaughnessey \& Hiegel, 1987; Officer, Biggs, Taft, Cronin, Tyler \& Boynton, 1984). The catalyst for current troubles dates to the 1930s when the human population in the Bay watershed nearly doubled and inorganic fertilizer use tripled (Boesch, Brinsfield \& Magnien, 2001; Zimmerman \& Canuel, 2000; Davidson, Merwin, Capper, Power \& Shivers, 1997; Cornwell, Conley, Owens \& Stevenson, 1996; Newcombe \& Horne, 1938). Today, DO is a central factor decreasing the capacity of the Chesapeake Bay to support economically important fisheries.

Hypoxia can severely stress, and in some instances eliminate, populations by decreasing growth rate, altering behavior, disrupting endocrine function, and interfering with other physiological activities (Wu, Zhou, Randall, Woo \& Lam, 2003; Taylor \& Miller, 2001). Most fishes immediately depress feeding activity to conserve energy and reduce oxygen consumption in hypoxic conditions. Food intake decreased significantly in Atlantic cod (Gadus morhua) and rainbow trout (Oncorhynchus mykiss) held at $60 \%$ water oxygen saturation (Chabot \& Dutil, 1999; Neji, Naimi, Lallier \& De La Noüe, 1991). Reduced food consumption results in growth impairment for juvenile turbot (Scopthalmus maximus) and Europen sea bass (Dicentrarchus labrax) in DO less than $3.5 \mathrm{mg} / \mathrm{L}$ (Pichavant, Person-Le-Ruyet, Le Bayon, Sévère, Le Roux \& Boeuf, 2001; Pichavant, Person-Le-Ruyet, Le Bayon, Sévère, Le Roux, Quéméner et al., 2000). 
Hypoxia also significantly reduced energy allocated to somatic growth and reproduction in carp (Cyprinus carpio; Zhou, Wu, Randall \& Lam, 2001). Thus, depressed feeding activity under hypoxic conditions is potentially harmful to population stability.

Acoustic signals play a key role in intraspecific and interspecific communication. Sound production by the family Syngnathidae (pipefishes and seahorses) involves bony edges of the skull, particularly the supraoccipital-coronet articulation (Colson, Patek, Brainerd \& Lewis, 1998; Fish \& Mowbray, 1970; Fish, 1953; Fish, Kelsey \& Mowbray, 1952). Seahorse sounds, described as loud clicks resembling the snapping of a finger against the thumb, have been recorded during introduction to new surroundings, courtship and spawning, and feeding (Colson et al., 1998; Bergert \& Wainwright, 1997; Fish \& Mowbray, 1970; Tarasov, 1963; Fish, 1954, 1953; Gill, 1905). Behavioral observations revealed a positive correlation between sound production and feeding strikes in two seahorse species (Colson et al., 1998). Reports on sound production by the closely related pipefishes are considerably rare. Studies have recorded clicking by Syngnathus louisanae (Burkenroad, 1931) and S. fuscus (Fish et al., 1952), but the context, mechanism, frequency, and duration of pipefish sounds have not been documented.

We recorded sounds produced during feeding by northern, Syngnathus fuscus, and dusky pipefishes, Syngnathus floridae, of the Chesapeake Bay region. Our first study explored the relationship between sound production and feeding. Next, under hypoxic conditions, we hypothesized food intake and,temporal frequency of sound production would decrease. Finally, by studying two sympatric species, we examined potential interspecific differences in hypoxia sensitivity. The purpose of this investigation is to propose the utilization of acoustic monitoring as an indicator of population changes in feeding. 


\section{Materials and methods}

\subsection{Study animals}

We collected pipefish by seining in the seasonally abundant shallow eelgrass beds (Zostera marina) of the Chincoteague Bay, VA, USA from May through September 2004-2005. Details of the site, collection technique, and reproductive condition of the pipefishes including sex ratios, growth rates, population size structure, and spawning synchrony are presented in Ripley and Foran (in press). Brooding S. fuscus and S. floridae males, along with other pipefish species, have been shown to feed less than conspecific gravid females (Teixeira \& Musick, 1995; Steffe, Westoby \& Bell, 1989; Svensson, 1988). To eliminate this potential source of variation, we used only non-brooding males in this study. Dissolved oxygen levels, water temperature, and salinity were recorded with a YSI 85 handheld meter (YSI Incorporated, Yellow Springs, OH, USA) and are presented in Ripley and Foran (in press). Pipefish were housed for a maximum of three days at the field station in aerated tanks with daily water changes before being transported to the laboratory in Kordon ${ }^{\circledR}$ breathing bags (Novalek Inc., Hayward, CA, USA) chilled with ice.

\subsection{Baseline feeding behavior}

Acclimation to laboratory conditions and diet spanned at least four weeks during which pipefish were housed in aerated, filtered 38 liter tanks at $24 \pm 1^{\circ} \mathrm{C}$ on a $14: 10$ photoperiod (6:00 on; 20:00 off). The purpose of the lengthy acclimation period was to minimize influences on respiratory physiology and/or behavior stemming from adverse field conditions, travel stress, and laboratory housing. Photoperiod mimicked the average seasonal trend for the collection location, while temperature was maintained on the low end of the seasonal range to ward off disease and parasite infections. We used artificial seawater (Instant Ocean) in the laboratory and decreased 
salinity from Bay averages of 30 to $20-25$ parts per thousand to prevent parasite transfer between animals (Ripley \& Foran, in press). Fish were separated by species and sex and maintained at a density of less than ten per tank. Pipefish were fed frozen mysid shrimp and Artemia to satiation three times daily.

For the baseline feeding observations, pipefish were moved to acoustically buffered 38 liter tanks maintained as described above. Acoustic buffering was achieved by standing tanks on a $4 \mathrm{~cm}$ rubber platform. Tanks held a single, large piece of non-living coral in the center to buffer $\mathrm{pH}$, thereby circumventing any $\mathrm{pH}$ changes from the build-up of carbon dioxide (Sagasti, Schaffner \& Duffy, 2001; Burnett, 1997). Artificial eelgrass fashioned from nylon rope filled the right side of the tank while the left contained the back filter but was otherwise bare. Pairs of conspecific, same sex fish were moved one at a time with 5 minutes separating the introduction of each. We recorded acoustic and visual behavior during this introduction event beginning 1 minute before the first fish was added to 10 minutes after the second addition for a total taping of 16 minutes. Food was not introduced during this time. Synchronous audiovisual data was recorded by an omnidirectional hydrophone (Aquarian Audio Products, Anacortes, WA, USA; model AQ-6; frequency range $20 \mathrm{~Hz}-100 \mathrm{kHz}$ ) connected to a Sony Hi8 video camera recorder (model no. CCD-TRV43) and a Hewlett Packard Pavilion zv5000 laptop computer. The video camera stood on a tripod approximately $1.5 \mathrm{~m}$ in front of the tank. We digitized acoustic data by the connection to the laptop with CoolEdit 2000 (Syntrillium Software Corporation, Phoenix, AZ, USA) and Raven 1.2 sound analysis software (Cornell Laboratory of Ornithology, Ithaca, NY, USA). Sounds were digitized at a 16-bit resolution and a sampling rate of $44.1 \mathrm{kHz}$. All pumps, filters, and heaters were turned off during recording sessions. 
Single sex, conspecific pairs were acclimated to the acoustic tanks for three to five days during which food was always introduced on the right, barren side of the tank to allow unobstructed viewing. Dissolved oxygen levels were documented prior to audiovisual recording. We videotaped and acoustically digitized the feeding event for 15 minutes starting with the introduction of food. Food was added to the right section of the tank in $0.33 \mathrm{~mL}$ increments every 5 minutes with a graduated, disposable pipette to ensure constant movement of available food. To quantify food consumption, we immediately anaesthsized both fish with 3aminobenzoic acid ethyl ester (MS222; Sigma Aldrich) in saltwater. Standard length (tip of the snout to the caudal peduncle) and weight were recorded. Ryer and Boehlert (1983) showed the time required for $S$. fuscus to completely evacuate a meal was 14.1 hours at $23^{\circ} \mathrm{C}$ with time decreasing at higher temperatures. The recording session was always the morning episode. Thus, the last feeding event was at least 16 hours earlier, indicating the entire content of the gut was consumed during the recording. Syngnathus fuscus and S. floridae possess relatively undifferentiated gastrointestinal tracts (Teixeira \& Musick, 1995; Ryer \& Orth, 1987). Therefore, the contents of the whole gastrointestinal tract were extracted and wet weight recorded. We repeated these procedures on 10 males and females of each species for a total of 40 individuals examined.

\subsection{Behavior and sound analysis}

Videotapes were reviewed noting sound production, behavioral accompaniment, context, position in the water column and tank, individual identity, and counter time. The frequency of behavioral pairing with sound production was calculated for each individual and averaged for the species. Non-parametric Spearman correlations compared sound production with food intake, or 
the number of Artemia consumed, and wet weight of gut content to investigate the accuracy of sound production as a measure of feeding behavior for S. fuscus and S. floridae.

Five sounds produced by each pipefish were randomly selected for acoustic analysis. Only sounds produced when the fish was positioned in the water column were analyzed. Background noise and artifacts characteristic of small tanks complicate acoustic recordings (Okumura, Akamatsu \& Yan, 2002; Yager, 1992; Parvulescu, 1967). Reflections and reverberations off the tank walls may interfere with parameter measurements when fish are resting on the bottom or against the side. This subset of analyzed sounds also ensured consistent sample sizes between exposure days during the hypoxia studies when sound production decreased. We measured two parameters: sound duration and peak frequency. Sound duration quantifies the temporal length of the sound and is calculated from the waveform. Peak frequency is the frequency at peak amplitude read from the spectrogram. Peak frequency is less affected by tank characteristics than other frequency assessments, making it the preferred measure in this study employing tanks of rather small size (de Amorim, 1996). We used Raven 1.2 to analyze sounds (FFT $=4095$, Hamming).

\subsection{Feeding and acoustic behavior in hypoxic waters}

Syngnathus fuscus and S. floridae pipefish were moved to acoustic tanks and videotaped as described in the baseline study. After a three to five day acclimation in normoxic conditions, DO levels were recorded and a 15-minute morning feeding session videotaped. This recording was designated day 0. Dissolved oxygen levels were then lowered over a four hour period by bubbling nitrogen gas. Similar abrupt oxygen changes take place in the Chesapeake Bay (Sagasti et al., 2001; Kuo \& Neilson, 1987). Two hypoxic levels were tested: 2 and 1 mg/L $\mathrm{O}_{2}$. Hypoxia, the level at which many animals suffocate, is defined as DO concentrations below 2 
mg/L (Diaz, 2001; Diaz \& Rosenberg, 1995; Nixon, 1995). We chose $1 \mathrm{mg} / \mathrm{L} \mathrm{O}_{2}$ as a second treatment because this level is lethal to Bay grasses (Holmer \& Bondgaard, 2001; Smith, Pregnall \& Alberte, 1988). Dissolved oxygen levels were maintained within $\pm 0.2 \mathrm{mg} / \mathrm{L}$ of the target concentration. The YSI 85 meter was calibrated every morning and experimental DO levels checked five times daily. As the typical duration of hypoxic episodes in the Chesapeake Bay lasts 5 days (Sagasti et al., 2001; Kuo, Neilson, Brubaker \& Ruzecki, 1993), the study spanned the same period. We videotaped morning feeding sessions on days 1,3 , and 5 . On the even days, $50 \%$ water changes were performed to maintain water quality and prevent the buildup of metabolic byproducts as the filters did not run during exposures. We established reservoirs of water of the appropriate DO level to be utilized during water changes to avoid large fluctuations in oxygen concentrations. Water quality was tested on odd days and measures kept within an optimum range (ammonia $<0.50$ parts per million $(\mathrm{ppm})$, nitrate $<10 \mathrm{ppm}$, nitrite $<$ $0.50 \mathrm{ppm}, \mathrm{pH}=8.2-8.6$ ). Following the feeding event on day 5 , we anaesthsized fish and recorded standard length and weight. Ten males and females of both species were tested at each hypoxia level for a total of 80 experimental pipefish.

Videotapes were reviewed noting the same measurements listed for the baseline study. The frequency of behavioral pairing with sound production was calculated for each individual and averaged for the species at both DO concentrations. Interspecific changes in food intake and sound production with hypoxia exposure were investigated for the two DO levels. Differences in sound production between oxygen concentrations were examined for each species. We randomly selected 5 sounds produced on day 0 and 3-5 sounds from each hypoxia recording for sound duration and peak frequency analysis. Differences in sound duration and frequency on day 0 versus days 1, 3 and 5 were investigated for individual pipefish. Individuals that did not 
produce sound on one or more days or only produced sound when resting on the bottom of the tank were excluded from this investigation of potential changes in sound structure due to the lack of data. All statistical analyses were performed with JMP 5.1.

\section{Results}

Dissolved oxygen concentrations in the Chincoteague Bay, VA, USA measured 4.6-9.3 mg/L during May-September 2004-2005 collections (Ripley \& Foran, in press). We assumed the site did not experience extended periods of low DO and experimental fish had not been previously exposed to chronic hypoxia.

This study recorded 53.85 hours of feeding activity, 19.05 hours of introduction to new surroundings, and 1.72 hours of courtship and spawning by S. fuscus and S. floridae with observation time divided equally between the two species.

\subsection{Feeding behavior}

Food intake by S. fuscus and S. floridae was accompanied by a head snap in which head and snout elevation was followed by a rapid return to the resting position. Behavioral observations determined each feeding strike resulted in the ingestion of one Artemia. Tallying feeding strikes therefore estimates food consumption. In both species, food intake was always accompanied by sound production and a head snap (Table 1). However, pipefish produced sound without ingesting food (Table 1). Each time a sound was produced, a head snap was also performed. Yet S. fuscus and S. floridae performed head snaps without sound accompaniment (Table 1).

Sound production was positively correlated with feeding strikes in $S$. fuscus $(\mathrm{r}=0.85, \mathrm{p}<$ 0.0001; Fig. 1(a)) and S. floridae (r =0.97, $\mathrm{p}<0.0001$; Fig. 1(a)). The number of sounds 
produced also showed a significant positive correlation with the wet weight of food in the gut of S. fuscus (r =0.60, p < 0.01; Fig. 1(b)) and S. floridae (r =0.51, p <0.001; Fig. 1(b)).

Sex differences in feeding behavior were not detected for S. floridae. Female S. fuscus ingested more food (2-way ANOVA, F = 12.62, $\mathrm{p}<0.0001$; post-hoc Tukey HSD, $\mathrm{Q}=2.69, \alpha=$ 0.05 (post-hoc test identical for subsequent comparisons)), contained a greater wet weight of food in the gut $(\mathrm{F}=6.76, \mathrm{p}=0.001)$, performed more head snaps $(\mathrm{F}=21.09, \mathrm{p}<0.0001)$, and produced more sounds $(\mathrm{F}=22.96, \mathrm{p}<0.0001)$ than conspecific males. Syngnathus fuscus females were also heavier $(F=18.63, \mathrm{p}<0.0001)$ and longer $(\mathrm{F}=17.91, \mathrm{p}<0.0001)$. This size dimorphism is characteristic of the species (Ripley \& Foran, in press). Weight was positively correlated with food intake $(r=0.68, p=0.001)$ and wet weight of ingested food $(r=0.72, p<$ 0.001). The sex differences in S. fuscus behavior can be attributed to larger females eating more food. Since size distinctions explain the behavioral differences, only interspecific distinctions were examined in the remaining analyses.

\subsection{Feeding click characterization}

Syngnathus fuscus and S. floridae produce high frequency, short duration clicks with food intake (Table 2; Fig. 2). Body weight was not related to peak frequency in either species (S. fuscus; $\mathrm{r}=0.02, \mathrm{p}=0.81 ;$ S. floridae $; \mathrm{r}=0.05, \mathrm{p}=0.44)$. Interspecific differences were detected in sound duration (Nested 2-way ANOVA, F =2.51, p = 0.02; post-hoc Student's t, $\mathrm{t}=1.97, \alpha=$ 0.05) and peak frequency (Nested 2-way ANOVA, $\mathrm{F}=6.67, \mathrm{p}<0.0001$; post-hoc Student's $\mathrm{t}, \mathrm{t}=$ 1.97, $\alpha=0.05)$. Syngnathus fuscus produce longer sounds of higher frequency.

Click production by $S$. fuscus and S. floridae was largely limited to feeding activity. Neither S. fuscus nor S. floridae clicked when moved individually or in same sex pairs to a new aquarium. Males aligned parallel and quivered with one another when courting females, but 
clicks were not produced. Courting pairs also exchanged quivers. Although low frequency sound production most likely accompanied aggressive and courtship quiver behavior, it was not quantified in this study. Both S. fuscus and S. floridae clicked when held out of water during field collections and in the laboratory.

3.3 Feeding behavior in $2 \mathrm{mg} / \mathrm{L} \mathrm{O}_{2}$

Syngnathus fuscus and S. floridae exhibited significant decreases in food intake after one day in $2 \mathrm{mg} / \mathrm{L} \mathrm{O}_{2}$ (2-way ANOVA, $\mathrm{F}=9.36, \mathrm{p}<0.0001$; post-hoc Tukey HSD, $\mathrm{Q}=2.60, \alpha=$ 0.05; Fig. 3(a)). Over the five day period of hypoxia, the frequency of feeding strikes did not change (Fig. 3(a)). Sound production by S. fuscus and S. floridae decreased significantly following one day of $2 \mathrm{mg} / \mathrm{L} \mathrm{O}_{2}$ and the number of clicks did not recover or wane during the hypoxia period (2-way ANOVA, $\mathrm{F}=6.80, \mathrm{p}<0.0001$; post-hoc Tukey HSD, $\mathrm{Q}=2.60, \alpha=0.05$; Fig. 3(b)). Species differed in the number of sounds produced with $S$. floridae clicking significantly less often than $S$. fuscus (post-hoc Student's t, $t=1.98, \alpha=0.05$; Fig. 3(b)). In this hypoxia study, pipefishes did not significantly differ in standard length (2-way ANOVA, F= 2.08, $\mathrm{p}=0.12$; Table 2) or weight (2-way ANOVA, $\mathrm{F}=1.38, \mathrm{p}=0.26$; Table 2) based on species or sex.

Many clicks produced at $2 \mathrm{mg} / \mathrm{L} \mathrm{O}_{2}$ by $S$. fuscus and $S$. floridae coincided with behaviors other than food intake. Every feeding strike was accompanied by sound production in both species. Sound production without food intake was greater for S. fuscus (2-way ANOVA, F = 4.97, $\mathrm{p}<0.0001$; post-hoc Student's $\mathrm{t}, \mathrm{t}=1.98, \alpha=0.05$; Fig. 4(a-b)). The significant interruption in the correlation of sound and food intake for $S$. fuscus appeared one day in $2 \mathrm{mg} / \mathrm{L}$ hypoxic conditions and showed the greatest disruption at day 5 (post-hoc Tukey HSD, Q = 2.60, $\alpha=0.05$; Fig. 4(a)). 
When food intake did not accompany sound production, one of four other behaviors corresponded with clicks in this study. Behaviors included a series of head snaps with a piece of food moving back and forth in the snout that eventually led to food expulsion, head snaps coupled with food expulsion, and head snaps at the water surface. The fourth behavior was solitary head snaps without any observable context. Head snaps in a series leading to food expulsion were the most performed of these behavioral accompaniments for both species $(S$. fuscus; 1-way ANOVA, F= 498.18, $\mathrm{p}<0.0001$; post-hoc Tukey-Kramer HSD, $\mathrm{Q}=2.58, \alpha=$ 0.05; Fig. 4(a); S. floridae; 1-way ANOVA, F = 179.93, $\mathrm{p}<0.0001$; post-hoc Tukey-Kramer HSD, $Q=2.59, \alpha=0.05$; Fig. 4(b)). Interspecific and hypoxia-induced differences were not observed in the performance of food expulsion $(F=0.61, p=0.75)$, repetitive head snaps $(F=$ 0.96, $\mathrm{p}=0.46)$, or solo head snaps $(\mathrm{F}=0.35, \mathrm{p}=0.93$; Fig. 4(a-b)). However, S. floridae coupled clicks with head snaps at the surface more often than S. fuscus during both the normoxic and hypoxic periods (2-way ANOVA, $\mathrm{F}=2.77, \mathrm{p}=0.01$; post-hoc Student's $\mathrm{t}, \mathrm{t}=1.98, \alpha=0.05$; Fig. 4(a-b)).

\subsection{Feeding behavior in $1 \mathrm{mg} / \mathrm{L} \mathrm{O}_{2}$}

Food intake by $S$. fuscus and $S$. floridae declined significantly in $1 \mathrm{mg} / \mathrm{L} \mathrm{O}_{2}$ (2-way ANOVA, F = 25.56, $\mathrm{p}<0.0001$; Fig. 5(a)). Feeding strikes decreased after one day in $1 \mathrm{mg} / \mathrm{L}$ $\mathrm{O}_{2}$ and did not change over the duration of exposure (post-hoc Tukey HSD, $\mathrm{Q}=2.60, \alpha=0.05$;

Fig. 5(a)). Overall S. fuscus performed more feeding strikes than S. floridae (post-hoc Student's $\mathrm{t}, \mathrm{t}=1.98, \alpha=0.05$; Fig. 5(a)). Sound production by $S$. fuscus and S. floridae also decreased significantly in $1 \mathrm{mg} / \mathrm{L} \mathrm{O}_{2}$ (2-way ANOVA, $\mathrm{F}=11.25, \mathrm{p}<0.0001$; Fig. 5(b)). Following one day of $1 \mathrm{mg} / \mathrm{L} \mathrm{O}_{2}$, sound production declined, remaining consistently low over the exposure (post-hoc Tukey HSD, Q = 2.60, $\alpha=0.05$; Fig. 5(b)). Syngnathus fuscus produced significantly 
more clicks than $S$. floridae (post-hoc Student's t, t $=1.98, \alpha=0.05$; Fig. 5(b)). Syngnathus fuscus females in this hypoxia treatment were longer (2-way ANOVA, $\mathrm{F}=6.18, \mathrm{p}=0.001$; posthoc Tukey HSD, Q = 2.69, $\alpha=0.05$; Table 2) and heavier (2-way ANOVA, F = 9.12, p = 0.0001; post-hoc Tukey HSD, Q = 2.69, $\alpha=0.05$; Table 2) than $S$. fuscus males.

Both species showed a similar breakdown in the correlation of sound production with food intake. All feeding strikes were accompanied by clicks, but after one day of $1 \mathrm{mg} / \mathrm{L} \mathrm{O}_{2}, S$. fuscus and S. floridae coupled sound production with food intake less often (2-way ANOVA, F = 9.18, $\mathrm{p}<0.0001$; Fig. 4(c-d)). The pairing of sound production with feeding strikes did not change over the course of hypoxia exposure for either species (post-hoc Tukey HSD, Q = 2.6, $\alpha$ $=0.05 ;$ Fig. 4(c-d)).

When sound production did not coincide with food intake, repetitive head snaps leading to food expulsion were the most performed behavioral accompaniment to click production for $S$. fuscus (1-way ANOVA, F = 112.34, p<0.0001; Fig. 4(c)) and S. floridae (1-way ANOVA, F = 41.65, p < 0.0001; Fig. 4(d)). Syngnathus floridae exhibited a significant decline in the frequency of food expulsion when DO was decreased to $1 \mathrm{mg} / \mathrm{L}$ (2-way ANOVA, F = 3.71, $\mathrm{p}=$ 0.001; post-hoc Tukey HSD, Q = 3.09, $\alpha=0.05$; Fig. 4(d)). Although both species clicked at the surface more frequently under $1 \mathrm{mg} / \mathrm{L} \mathrm{O}_{2}(\mathrm{~F}=3.45, \mathrm{p}=0.002$; post-hoc Tukey HSD, $\mathrm{Q}=2.61, \alpha$ $=0.05$ ), S. floridae performed this behavior more often than $S$. fuscus (post-hoc Student's $\mathrm{t}, \mathrm{t}=$ 1.98, $\alpha=0.05$; Fig. 4(c-d)). Interspecific and hypoxia-induced differences were not observed in the performance of repetitive $(F=1.14, p=0.34)$ or solo head snaps $(F=0.67, p=0.70$; Fig. $4(\mathrm{c}-\mathrm{d}))$. 


\subsection{Characterization of clicks produced in hypoxic conditions}

Analysis of sounds produced in $2 \mathrm{mg} / \mathrm{L} \mathrm{O}_{2}$ did not reveal any significant hypoxia-induced changes in sound duration or peak frequency for either species (Tables 2 and 3). Duration and peak frequency also did not change in the $1 \mathrm{mg} / \mathrm{L} \mathrm{O}_{2}$ study (Tables 2 and 3).

Comparisons between clicks produced during feeding strikes versus those accompanying head snaps before food expulsion did not uncover significant differences in sound parameters (Table 3).

Both species responded to low DO levels with a reduction in sound production. Syngnathus fuscus and $S$. floridae in $2 \mathrm{mg} / \mathrm{L} \mathrm{O}_{2}$ produced more clicks than conspecifics in 1 $\mathrm{mg} / \mathrm{L} \mathrm{O}_{2}$ (S. fuscus; post-hoc Student's t, $\mathrm{t}=1.98, \alpha=0.05$; Fig. 6(a); S. floridae; post-hoc Student's t, $\mathrm{t}=1.98, \alpha=0.05$; Fig. 6(b)).

\section{Discussion}

Here we detail the results of two studies. The first study assessed the utility of sound production as a measure of feeding activity. The context of sound production and the characters of these sounds (i.e. duration and peak frequency) were documented. In S. fuscus and S. floridae, sound production was not recorded during competition, courtship and spawning, or the introduction to new surroundings. Sound always accompanied food intake with both species performing head snaps with sound production. The sound is a high frequency, short duration click which does not differ with body size, sex, or species. The second experiment recorded changes in sound production and feeding activity when DO levels were hypoxic. Both species displayed significant reductions in feeding behavior and sound production within 24 hours of hypoxic conditions. Syngnathus fuscus produced fewer sounds and feed less than S. floridae, which were observed to click at the water surface in oxygen limited conditions. These results 
suggest altered feeding behavior should be considered in acoustic monitoring of populations under hypoxic conditions.

Sound production serves as an accurate measure of food intake in S. fuscus and $S$. floridae. Regardless of DO concentration, $100 \%$ of feeding strikes were accompanied by sound production. Observations of Syngnathid seahorses noted $93 \%$ of Hippocampus zosterae and $100 \%$ of $H$. erectus feeding strikes were accompanied by clicks (Colson et al., 1998). Feeding strikes by $H$. zosterae that failed to produce detectable clicks showed reduced relative angular movements of skull components (Colson et al., 1998). The prey capture sequence for Hippocampus seahorses involves a nearly synchronous, extremely rapid head elevation and mouth opening with clicks produced within 2 msec of head elevation (Colson et al., 1998; Bergert \& Wainwright, 1997). Considering the similarity with S. fuscus and S. floridae feeding strikes, restricted movement may explain the performance of head snaps unaccompanied by sound in this study.

We believe $S$. fuscus and $S$. floridae feeding clicks are produced by a stridulation mechanism. Identifying traits of stridulation sound include a non-harmonic structure (i.e. the spectrogram does not resolve into a series of horizontal, parallel bars at harmonic intervals) and a wide frequency spread with the maximum energy located in the higher end of the spectrum (Tavolga, 1964; Fish, 1954; Fish et al., 1952). Spectrograms of clicks produced with any behavioral accompaniment by S. fuscus and S. floridae never revealed harmonics. Pipefish peak frequency measurements were high, matching the ranges of $H$. zosterae $(2650-3430 \mathrm{~Hz})$ and $H$. erectus $(1960$ - $2370 \mathrm{~Hz}$; Colson et al., 1998). Swimbladder and pharyngeal teeth-generated sounds provide an indication of male size in courtship and competitive interactions as larger fish produce sounds of lower frequency (Lobel \& Mann, 1995; Myrberg, Ha \& Shamblott, 1993). 
The absence of this correlation in S. fuscus and S. floridae and other stridulation species can be attributed to the wide frequency range of these sounds (Ladich, 1997; Tavolga, 1964; Fish, 1954; Fish et al., 1952). Colson et al. (1998) surgerically filed the bony supraoccipital-coronet articulation of $H$. zosterae and $H$. erectus, eliminating sound production and confirming a stridulation mechanism. Analogous coupling of food intake with clicks, feeding strike head movements, and sound parameters suggest a comparable skull articulation, but differences in pipefish head morphology and posture warrant further investigations to identify the specific structures and mechanism.

The functional significance of Syngnathid feeding clicks is not known. Causal observations did not indicate a role of feeding clicks in communicating the presence of food or deterring conspecifics (Amorim, Stratoudakis \& Hawkins, 2004; Amorim \& Hawkins, 2000). Seahorse studies have documented clicks during courtship and spawning (Colson et al., 1998; Fish \& Mowbray, 1970; Fish, 1954). We did not detect sound production during reproduction in S. fuscus and S. floridae. Synganthid species are generally divided among polygamous pipefish and monogamous seahorses with a few pipefish species exhibiting monogamy (Carcupino, Baldacci, Mazzini \& Franzoi, 2002; Vincent, Ahnesjö, Berglund \& Rosenqvist, 1992). Distinctions in reproductive strategies may translate into differences in click production. Syngnathid feeding clicks could be similar to the feeding sounds of rainbow trout and may be an unintentional product of the feeding mechanism, playing no communicative role at all (Phillips, 1989). Future studies should investigate the ecological and behavioral implications of sound production in Syngnathidae.

The Chincoteague Bay mirrors the habitat and community structure of the neighboring Chesapeake without the water quality problems (Kiddon, Paul, Buffum, Strobel, Hale, Cobb et 
al., 2003; Dauer \& Alden, 1995). Dissolved oxygen concentrations rarely measured below state water quality standards of $5 \mathrm{mg} / \mathrm{L}$ in our monitoring or Kiddon et al.'s (2003) data from 1997-98, granting the Chincoteague Bay an index of environmental integrity rating of "good" with less than $20 \%$ of the area exhibiting impairment (Ripley \& Foran, in press). The pipefish in this study, accordingly, were collected from a relatively pristine site and the behaviors observed are assumed to be unaltered by prior exposure to adverse environmental conditions.

Pipefishes are ideal model organisms for studying disturbances to estuarine habitats due to their seasonal abundance and behavioral responses. Syngnathidae is among the most abundant fish families occupying estuarine grass beds worldwide, including the Atlantic-Mediterranean and Indo-Pacific regions (Howard \& Koehn, 1985; Pollard, 1984). In the Chesapeake Bay, $S$. fuscus ranks second and S. floridae sixth in abundance among fishes (Orth \& Heck, 1980). The migration of S. fuscus and S. floridae from deeper waters to shallow eelgrass beds overlaps summer hypoxic events (Ripley \& Foran, in press; Wang et al., 2001; Lazzari \& Able, 1990; Holland et al., 1987; Officer et al., 1984). As swimming speed and elevated predation risk to brooding males limits movement, pipefish are not able to flee to more oxygenated areas as is common for other fish species (Ashley-Ross, 2002; Wannamaker \& Rice, 2000; Roelke \& Sogard, 1993; Breitburg, 1992). Adult S. fuscus and S. floridae survived and, in some cases, continued to feed at $1 \mathrm{mg} / \mathrm{L} \mathrm{O}_{2}$. This study demonstrated these two pipefish species are tolerant to DO concentrations below levels lethal to most commercially important species of the Bay including the bay grasses which serve as pipefish spawning habitat (Miller, Poucher \& Coiro, 2002; Diaz \& Rosenberg, 1995; Davis, 1975). Accordingly, acoustic monitoring of pipefish during hypoxic events is a rather conservative estimate of disturbance because the consequences to commercial species are probably more severe. 
Behavior is very sensitive to contaminants, demonstrating links between effects at different levels of organization as changes at the biochemical level may be readily translated into population level impacts (Shumway, 1999; Weis, Smith \& Zhou, 1999; Morgan \& Kiceniuk, 1990). Hypoxia immediately reduced feeding in S. fuscus and S. floridae. For S. fuscus, energy assimilation depends on temperature. Higher water temperatures speed gastric evacuation and increase the number of prey items processed (Ryer \& Boehlert, 1983). With summer hypoxic events correlating to periods of high prey availability, S. fuscus energy assimilation can be greatly limited by decreased food intake following only one day of hypoxia. The pipefish lifetime spans 2 years, while most Chesapeake Bay epifaunal species live only one season (Ripley \& Foran, in press; Able \& Fahay, 1998; Campbell \& Able, 1998; Abbe, 1987). Short disruptions in feeding could impact a considerable portion of an animal's lifetime. Even brief reductions in food intake may profoundly influence growth, health, or reproduction as resources are devoted to survival instead of gamete production.

Pipefish feeding activity is an important component in the transfer of carbon from planktonic to benthic food webs (Ryer \& Boehlert, 1983). Long snouts characterize S. floridae (1.65-1.85 in head) and shorter snout-to-head lengths distinguish S. fuscus (2-2.5 in head; Murdy, Birdsong \& Musick, 2002; Teixeira \& Musick, 1995; Herald, 1965; Breder, 1929). Accordingly, S. floridae in the Chesapeake Bay region prefer to prey upon various sized grass shrimp (Palaemonetes pugio), while S. fuscus appear to be more gape-limited, only feeding on small crustaceans (Teixeira \& Musick, 1995; Ryer \& Orth, 1987; Ryer \& Boehlert, 1983). Amphipods, particularly Gammarus mucronatus, comprise the majority of the diet of S. fuscus and in fact, S. fuscus predation is believed to largely control populations of this amphipod (Ryer 
\& Orth, 1987). Reduced predation associated with hypoxia could impact community dynamics in estuarine food webs.

Our observations revealed choking-like repetitive head snaps and food expulsion prevailed in hypoxic conditions when sound coincided with activities besides food consumption. Limited energy availability and expenditure may be preventing food from traveling the entire distance of the snout during ingestion. Differences in interspecific snout length did not translate into increased performance of these behaviors by S. floridae (Murdy et al., 2002; Teixeira \& Musick, 1995; Herald, 1965; Breder, 1929). Measurement of angular movements during head snaps would indicate reductions in feeding force. Energy wasted choking on and expelling food may exceed energy acquisition. The danger of having food caught in the snout as well as these energy costs may account for reduced food intake. Decreased locomotion conserves energy and thus, reduced swimming may also be the cause for the decline in feeding as searching for and capturing prey would be limited (Wu, 2002). Both species, but more so for S. floridae, gulped air at the surface in hypoxic conditions. Naked gobies effectively use aquatic surface respiration (ASR) to escape low oxygen in the field (Breitburg, 1992). By swimming to the surface, fish can irrigate their gills with more highly oxygenated surface water (Gee \& Gee, 1991; Kramer, 1987). Due to inherent and hypoxia-induced swimming constraints, pipefish appear to employ the same behavior. Anatomical specializations associated with surface respiration in pipefishes were not investigated in this study.

Syngnathus fuscus and S. floridae show interspecific differences in hypoxia sensitivity. Compared to S. floridae, S. fuscus demonstrated more frequent production of clicks accompanying choking, food expulsion, and solitary head snaps and a decreased tendency to perform ASR. Differences in geographic distributions may offer an explanation for these 
distinctions. A northern range from Halifax to North Carolina characterizes $S$. fuscus, while $S$. floridae are common from the Chesapeake Bay to Panama (Dawson, 1982). These distributions translate into differences in seasonal recruitment to the Chesapeake and Chincoteague Bays. Syngnathus fuscus abundance peaks an entire month before $S$. floridae in late July and early August (Ripley \& Foran, in press; Mercer, 1973). Hypoxia problems dominate late summer in warm, southern bodies of water with large human populations and abundant agricultural activity (Diaz, 2001). Common hypoxia events will correspond to when and where S. floridae are abundant. Hence, prevalence in areas plagued with low DO is consistent with decreased sensitivity and/or adaptation.

The practicality of acoustically monitoring pipefish feeding clicks is confounded by the variety of sympatric sound producing organisms. Snapping shrimp (Crangonidae), mussels (Mytilidae), sea urchins (Echinometridae), and various crabs produce stridulation sounds in estuarine and coastal ecosystems (Fish, 1964). Still, acoustic monitoring is feasible and a valuable tool to employ (Shumway, 1999). Passive acoustic detection of the damselfish, Dascyllus albisella, in the field has allowed reproductive activity to be monitored over long periods and wide spatial scales (Mann \& Lobel, 1995). Rather than specifically pinpoint pipefish feeding clicks, an array of hydrophones could record overall noise levels for comparisons between sites. Quieter locales resulting from either a decline in sound production as illustrated in this study or a decrease in density from physical avoidance would suggest adverse environmental conditions.

\section{Acknowledgements}

Pipefish collection was approved by the Commonwealth of Virginia Marine Resources Commission (permits 04-22 and 05-18). All animal care and methods complied with regulations 
enforced by the West Virginia University Animal Care and Use Committee (protocol number 030501, November 2003). We thank the Marine Science Consortium of Wallops Island, Virginia for the use of their facility and equipment. We also thank E. Anderson, D. Hardee, J. Marshall, A. Martin, W. Sites, T. Stueckle, and R. Torres for assistance in field collections and laboratory maintenance. This research was supported in part by a student research award to JR from the Chesapeake and Potomac Regional Chapter of the Society of Environmental Toxicology and Chemistry, the Oak Ridge Associated Universities, the West Virginia University Research Corporation, and the West Virginia University Department of Biology.

\section{References}

Abbe, G.R. (1987). Epifauna. In K.L. Heck (Ed.), Ecological studies in the middle reach Chesapeake Bay: Calvert Cliffs, lecture notes on coastal and estuarine studies No. 23 (pp. 82-96). New York: Springer-Verlang.

Able, K.W., \& Fahay, M.P. (1998). The first year in the life of estuarine fishes in the middle Atlantic Bight (pp. 130-132). New Jersey: Rutgers University Press.

Amorim, M.C., \& Hawkins, A.D. (2000). Growling for food: acoustic emissions during competitive feeding of the streaked gurnard. Journal of Fish Biology, 57, 895-907.

Amorim, M.C.P., Stratoudakis, Y., \& Hawkins, A.D. (2004). Sound production during competitive feeding in the grey gurnard. Journal of Fish Biology, 65, 182-194.

Ashley-Ross, M.A. (2002). Mechanical properties of the dorsal fin muscle of seahorse (Hippocampus) and pipefish (Syngnathus). Journal of Experimental Zoology, 293, 561577. 
Bergert, B.A., \& Wainwright, P.C. (1997). Morphology and kinematics of prey capture in the syngnathid fishes Hippocampus erectus and Syngnathus floridae. Marine Biology, 127, $563-570$.

Boesch, D.F., Brinsfield, R.B., \& Magnien, R.E. (2001). Chesapeake Bay eutrophication: scientific understanding, ecosystem restoration, and challenges for agriculture. Journal of Environmental Quality, 30, 303-320.

Breder, C.M. (1929). Field book of marine fishes of the Atlantic coast. New York: G. P. Putnam's Sons.

Breitburg, D.L. (1990). Near-shore hypoxia in the Chesapeake Bay: patterns and relationships among physical factors. Estuarine, Coastal and Shelf Science, 30, 593-609.

Breitburg, D.L. (1992). Episodic hypoxia in Chesapeake Bay: interacting effects of recruitment, behavior, and physical disturbance. Ecological Monographs, 62, 525-546.

Burkenroad, M.D. (1931). Notes on the sound-producing marine fishes of Louisiana. Copeia, $1931,20-29$.

Burnett, L.E. (1997). The challenges of living in hypoxic and hypercapnic aquatic environments. American Zoology, 37, 633-640.

Campbell, B.C., \& Able, K.W. (1998). Life history characteristics of the Northern pipefish, Syngnathus fuscus, in Southern New Jersey. Estuaries, 3, 470-745.

Carcupino, M., Baldacci, A., Mazzini, M., \& Franzoi, P. (2002). Functional significance of the male brood pouch in the reproductive strategies of pipefishes and seahorses: A morphological and ultrastructural comparative study on three anatomically different pouches. Journal of Fish Biology, 61, 1465-1480. 
Chabot, D., \& Dutil, J.D. (1999). Reduced growth of Atlantic cod in non-lethal hypoxic conditions. Journal of Fish Biology, 55, 472-491.

Colson, D.J., Patek, S.N., Brainerd, E.L., \& Lewis, S.M. (1998). Sound production during feeding in Hippocampus seahorses (Syngnathidae). Environmental Biology of Fishes, 51, 221-229.

Cornwell, J.C., Conley, D.J., Owens, M., \& Stevenson, J.C. (1996). A sediment chronology of the eutrophication of the Chesapeake Bay. Estuaries, 19, 488-499.

Dauer, D.M., \& Alden, R.W. (1995). Long-term trends in the macrobenthos and water quality of the lower Chesapeake Bay (1985-1991). Marine Pollution Bulletin, 2, 840-850.

Davidson, S.G., Merwin, J.G., Capper, J., Power, G., \& Shivers, F.R. (1997). Chesapeake waters: four centuries of controversy, concern, and legislation. Centreville, MD: Tidewater Publications.

Davis, J.C. (1975). Minimal dissolved oxygen requirements of aquatic life with emphasis on Canadian species: a review. Journal of the Fisheries Research Board of Canada, 32, 2295-2232.

Dawson, C.E. (1982). Family Syngnathide. In J.E. Bölke (Ed.), Fishes of the Western North Atlantic, part eight, order Gasterosteiformes, suborder Syngnathoidei (pp. 1-172). New Haven, Connecticut: Yale University.

de Amorim, M.C.P. (1996). Sound production in the blue-green damselfish, Chromis viridis (Cuvier, 1830) (Pomacentridae). Bioacoustics, 6, 265-272.

Diaz, R.J. (2001). Overview of hypoxia around the world. Journal of Environmental Quality, 2, 275-281. 
Diaz, R.J. \& Rosenberg, R. (1995). Marine benthic hypoxia: a review of its ecological effects and the behavioural responses of benthic macrofauna. Oceanography and Marine Biology Annual Review, 22, 245-303..

Fish, M.P. (1953). The production of underwater sound by the Northern seahorse, Hippocampus hudsonius. Copeia, 2, 93-94.

Fish, M.P. (1954). The character and significance of sound production among fishes of the Western North Atlantic. Bulletin of the Bingham Oceanographic Collection, 14, 1-109.

Fish, M.P. (1964). Biological sources of sustained ambient sea noise. In W.H. Tavolga (Ed.), Marine Bioacoustics (pp. 175-194). New York: Pergamon Press.

Fish, M.P., \& Mowbray, W.H. (1970). Sounds of western North Atlantic fishes (pp. 19). Baltimore: Johns Hopkins Press.

Fish, M.P., Kelsey, J.A.S., \& Mowbray, W.H. (1952). Studies on the production of underwater sound by North Atlantic coastal fishes. Journal of Marine Research, 11, 180-193.

Gee, J.H., \& Gee, P.A. (1991). Reactions of gobioid fishes to hypoxia: buoyancy control and aquatic surface respiration. Copeia, 1991, 17-28.

Gill, T. (1905). The life history of the sea horses (Hippocampids). Proceedings of the United States National Museum, 1408, 805-814.

Goldberg, E.D. (1995). Emerging problems in the coastal zone for the twenty-first century. Marine Pollution Bulletin, 31, 152-158.

Herald, E.S. (1965). Studies on the Atlantic American pipefishes with descriptions of new species. Proceedings of the California Academy of Sciences, 32, 363-375.

Holland, A.F., Shaughnessey, A.T., \& Hiegel, M.H. (1987). Long-term variation in a mesohaline Chesapeake Bay macrobenthos: spatial and temporal patterns. Estuaries, 10, 227-245. 
Holmer, M., \& Bondgaard, E.J. (2001). Photosynthetic and growth response of eelgrass to low oxygen and high sulfide concentrations during hypoxic events. Aquatic Botany, 70, 2938.

Howard, R.K., \& Koehn, J.D. (1985). Population dynamics and feeding ecology of pipefish (Syngnathidae) associated with eelgrass beds of Western Port, Victoria. Australian Journal of Marine and Freshwater Research, 36, 361-370.

Kiddon, J.A., Paul, J.F., Buffum, H.W., Strobel, C.S., Hale, S.S., Cobb, D., et al. (2003). Ecological condition of US Mid-Atlantic estuaries, 1997-1998. Marine Pollution Bulletin, 46, 1224-1244.

Kramer, D.L. (1987). Dissolved oxygen and fish behavior. Environmental Biology of Fishes, 18, 81-92.

Kuo, A.Y., \& Neilson, B.J. (1987). Hypoxia and salinity in Virginia estuaries. Estuaries, 10, 277-283.

Kuo, A.Y., Neilson, B.J., Brubaker, J.M., \& Ruzecki, E.P. (1993). Data report: hypoxia in the York River, 1991. Virginia Institute of Marine Science Data Report No. 47, Gloucester Point, Virginia.

Ladich, F. (1997). Comparative analysis of swimbladder (drumming) and pectoral (stridulation) sounds in three families of catfishes. Bioacoustics, 8, 185-208.

Lazzari, M.A., \& Able, K.W. (1990). Northern pipefish, Syngnathus fuscus, occurrences over the Mid-Atlantic Bight continental shelf: evidence of seasonal migration. Environmental Biology of Fishes, 27, 177-185.

Lobel, P.S., \& Mann, D.A. (1995). Spawning sounds of the damselfish, Dascyllus albisella (Pomacentridae) and relationship to male size. Bioacoustics, 6, 187-198. 
Mann, D.A., \& Lobel, P.S. (1995). Passive acoustic detection of sounds produced by the damselfish Dascyllus albisella (Pomacentridae). Bioacoustics, 6, 199-213.

Mercer, L.P. (1973). The comparative ecology of two species of pipefish (Syngnathidae) in the York River, Virginia (pp. 37). M.S. Thesis, Virginia Institute of Marine Science, The College of William and Mary, Gloucester Point, Virginia.

Miller, D.C., Poucher, S.L., \& Coiro, L. (2002). Determination of lethal dissolved oxygen levels for selected marine and estuarine fishes, crustaceans, and a bivalve. Marine Biology, 140, 287-296.

Morgan, M.J., \& Kiceniuk, J.W. (1990). Effect of fenitrothion on the foraging behavior of juvenile Atlantic salmon. Environmental Toxicology and Chemistry, 9, 489-495.

Murdy, E.O., Birdsong, R.S., \& Musick, J.A. (2002). Fishes of the Chesapeake Bay. Washington, D.C.: Smithsonian Institution Press.

Myrberg, A.A., Jr., Ha, S.J., \& Shamblott, M.J. (1993). The sounds of bicolor damselfish (Pomacentrus partitus), predicotrs of body size and a spectral basis for individual recognition and assessment. Journal of the Acoustical Society of America, 94, 3067-3070.

Neji, H., Naimi, N., Lallier, R., \& De La Noüe, J. (1991). Relationships between feeding, hypoxia, digestibility and experimentally induced furnunculosis in rainbow trout. Fish Nutrition in Practice, 61, 187-197.

Newcombe, C.L., \& Horne, W.A. (1938). Oxygen poor waters in the Chesapeake Bay. Science, 88,80

Nixon, S.W. (1990). Marine eutrophication: a growing international problem. Ambio, 3, 101.

Nixon, S.W. (1995). Coastal marine eutrophication: a definition, social causes, and future concerns. Ophelia, 41, 199-219. 
Officer, C.B., Biggs, R.B., Taft, J.L., Cronin, L.E., Tyler, M.A., \& Boynton, W.R. (1984). Chesapeake Bay anoxia: origin, development and significance. Science, 233, 22-27.

Okumura, T., Akamatsu, T., \& Yan, H.Y. (2002). Analyses of small tank acoustics: empirical and theoretical approaches. Bioacoustics, 12, 330-332.

Orth, R.J., \& Heck, J.K.L. (1980). Structural components of eelgrass (Zostera marina) meadows in the lower Chesapeake Bay - fishes. Estuaries, 4, 278-288.

Parvulescu, A. (1967). The acoustics of small tanks. In W.N. Tavolga (Ed.), Marine bioacoustics (pp. 7-13). New York: Pergamon Press.

Phillips, M.J. (1989). The feeding sounds of rainbow trout, Salmo gairdneri Richardson. Journal of Fish Biology, 35, 589-592.

Pichavant, K., Person-Le-Ruyet, J., Bayon, N.L., Sévère, A., Le Roux, A., \& Boeuf, G. (2001). Comparative effects of long-term hypoxia on growth, feeding and oxygen consumption in juvenile turbot and European sea bass. Journal of Fish Biology, 59, 875-883.

Pichavant, K., Person-Le-Ruyet, J., Bayon, N.L., Sévère, A., Le Roux, A., Quéméner., L., et al. (2000). Effects of hypoxia on growth and metabolism of juvenile turbot. Aquaculture, $188,103-114$.

Pollard, D.A. (1984). A review of ecological studies on seagrass-fish communities, with particular reference to recent studies in Australia. Aquatic Botany, 18, 3-42.

Ripley, J.L., \& Foran, C.M. (in press). Population structure, growth rates, and seasonal abundance of two Syngnathus pipefish species. Estuaries and Coasts.

Roelke, D.L., \& Sogard, S.M. (1993). Gender-based differences in habitat selection and activity level in the Northern pipefish (Syngnathus fuscus). Copeia, 2, 528-532. 
Ryer, C.H., \& Boehlert, G.W. (1983). Feeding chronology, daily ration, and the effects of temperature upon gastric evacuation in the pipefish, Syngnathus fuscus. Environmental Biology of Fishes, 3/4, 301-306.

Ryer, C.H., \& Orth, R.J. (1987). Feeding ecology of the Northern pipefish, Syngnathus fuscus, in a seagrass community of the lower Chesapeake Bay. Estuaries, 4, 330-336.

Sagasti, A., Schaffner, L.C., \& Duffy, J.E. (2001). Effects of periodic hypoxia on mortality, feeding and predation in an estuarine epifaunal community. Journal of Experimental Marine Biology and Ecology, 258, 257-283.

Shumway, C.A. (1999). A neglected science: applying behavior to aquatic conservation. Environmental Biology of Fishes, 55, 183-201.

Smith, R.D., Pregnall, A.M., \& Alberte, R.S. (1988). Effects of anaerobiosis on root metabolism of Zostera marina (eelgrass): implications for survival in reducing sediments. Marine Biology, 98, 131-141.

Steffe, A.S., Westoby, M., \& Bell, J.D. (1989). Habitat selection and diet in two species of pipefish from seagrass: sex differences. Marine Ecology Progress Series, 55, 23-30.

Svensson, I. (1988). Reproductive costs in two sex role reversed pipefish species (Syngnathidae). Journal of Animal Ecology, 57, 929-942.

Tarasov, N.I. (1963). Zhivyye zvuki morya (The live sounds of the sea) (pp. 88). Washington, D.C.: U.S. Naval Oceanographic Office.

Tavolga, W.N. (1964). Sonic characteristics and mechanisms in marine fishes. In W.N. Tavolga (Ed.), Marine bioacoustics (pp. 195-211). New York: Pergamon Press. 
Taylor, J.C., \& Miller, J.M. (2001). Physiological performance of juvenile southern flounder, Paralichthys lethostigma (Jordan and Gilbert, 1884), in chronic and episodic hypoxia. Journal of Experimental Marine Biology and Ecology, 258, 195-214.

Teixeira, R.L., \& Musick, J.A. (1995). Trophic ecology of two congeneric pipefishes (Syngnathidae) of the lower York River, Virginia. Environmental Biology of Fishes, 43, 295-309.

Vincent, A., Ahnesjö, I., Berglund, A., \& Rosenqvist, G. (1992). Pipefishes and seahorses: are they all sex role reversed? Trends in Ecology and Evolution, 237-241.

Wang, P., Batiuk, R., Linker, L., \& Shenk, G. (2001). Assessment of best management practices for improvement of dissolved oxygen in Chesapeake Bay estuary. Water Science and Technology, 7, 173-180.

Wannamaker, C.M., \& Rice, J.A. (2000). Effects of hypoxia on movements and behavior of selected estuarine organisms from the southeastern United States. Journal of Experimental Marine Biology and Ecology, 249, 145-163.

Weis, J.S., Smith, G.M., \& Zhou, T. (1999). Altered predator/prey behavior in polluted environments: implications for fish conservation. Environmental Biology of Fishes, 55, 43-51.

Wu, R.S.S. (2002). Hypoxia: from molecular responses to ecosystem responses. Marine Pollution Bulletin, 45, 35-45.

Wu, R.S.S., Zhou, B.S., Randall, D.J., Woo, N.Y.S., \& Lam, P.K.S. (2003). Aquatic hypoxia is an endocrine disruptor and impairs fish reproduction. Environmental Science and Technology, 37, 1137-1141. 
Yager, D.D. (1992). Underwater acoustic communication in the African pipid frog Xenopus borealis. Bioacoustics, 4, 1-24.

Zhou, B.S., Wu, R.S., Randall, D.J., \& Lam, P.K. (2001). Bioenergetics and RNA/DNA ratios in the common carp (Cyprinus carpio) under hypoxia. Journal of Comparative Physiology $B, 171,49-57$.

Zimmerman, A.R., \& Canuel, E.A. (2000). A geochemical record of eutrophication and anoxia in Chesapeake Bay sediments: anthropogenic influence on organic matter composition. Marine Chemistry, 69, 117-137. 
Table 1

Behavioral pairings for Syngnathus fuscus (bold text) and Syngnathus floridae

\begin{tabular}{lccc}
\hline & Sound Production & Food Intake* & Head Snap \\
\hline Sound Production & & $\mathbf{6 8 . 6} \pm \mathbf{3 . 4}$ & $\mathbf{1 0 0}$ \\
\hline Food Intake & $\mathbf{1 0 0}$ & $82.8 \pm 4.1$ & 100 \\
\hline \multirow{2}{*}{ Head Snap } & 100 & & $\mathbf{1 0 0}$ \\
\hline
\end{tabular}

* The mean \pm SE frequency (\%) of coupling the actions listed down the left column with the actions listed along the top are reported. For example, $68.6 \%$ of the sounds produced and $66.0 \%$ of the head snaps performed by $S$. fuscus accompany food intake. 
Table 2

Ranges of individual sizes and sound parameters of feeding clicks for the baseline and hypoxia studies

\begin{tabular}{cccccc}
\hline & $\begin{array}{c}\text { Weight } \\
(\mathrm{mg})\end{array}$ & $\begin{array}{c}\text { Standard } \\
\text { Length } \\
(\mathrm{mm})\end{array}$ & $\begin{array}{c}\text { Number } \\
\text { of Sounds } \\
(\mathrm{n})\end{array}$ & $\begin{array}{c}\text { Sound } \\
\text { Duration } \\
(\mathrm{ms})\end{array}$ & $\begin{array}{c}\text { Peak } \\
\text { Frequency } \\
(\mathrm{Hz})\end{array}$ \\
\hline Baseline Study & $978-3312$ & $131-185$ & 50 & $7-17$ & $1310-1440$ \\
S. fuscus Males & $2371-3848$ & $171-230$ & 50 & $8-16$ & $1298-1456$ \\
Females & $930-2272$ & $138-167$ & 50 & $5-16$ & $996-1378$ \\
S. floridae Males & $861-2153$ & $129-164$ & 50 & $5-22$ & $988-1446$ \\
Females & & & & & \\
\hline Hypoxia 2 mg/L & $524-1238$ & $116-157$ & 158 & $3-15$ & $985-1449$ \\
S. fuscus Males & $1157-1857$ & $146-176$ & 164 & $4-13$ & $1039-1397$ \\
Females & $718-2104$ & $128-157$ & 152 & $3-16$ & $1019-1308$ \\
S. floridae Males & $750-2472$ & $127-176$ & 182 & $5-15$ & $1071-1405$ \\
Females & & & & & \\
\hline Hypoxia 1 mg/L & $673-2625$ & $131-181$ & 113 & $4-15$ & $1087-1416$ \\
S. fuscus Males & $593-4008$ & $124-220$ & 111 & $3-11$ & $921-1405$ \\
Females & $717-1880$ & $128-157$ & 88 & $4-15$ & $980-1395$ \\
S. floridae Males & $751-2597$ & $127-186$ & 107 & $4-16$ & $942-1373$ \\
Females & & & & & \\
\hline
\end{tabular}


Table 3

Summary of p-values investigating individual differences in sound parameters over the course of hypoxia exposure and between clicks produced during food intake versus repetitive head snaps leading to food expulsion

\begin{tabular}{|c|c|c|c|c|c|c|c|c|}
\hline Parameter & $\begin{array}{l}\text { S. fuscus } \\
\mathrm{n}\end{array}$ & $\begin{array}{l}\text { p-values } \\
\text { Median }\end{array}$ & Min & Max & $\begin{array}{l}\text { S. floridae } \\
\mathrm{n}\end{array}$ & $\begin{array}{l}\text { p-values } \\
\text { Median }\end{array}$ & Min & Max \\
\hline \multicolumn{9}{|c|}{$\begin{array}{l}\text { Changes with exposure duration } \\
2 \mathrm{mg} / \mathrm{L}\end{array}$} \\
\hline Duration & 14 & 0.4006 & 0.2112 & 0.9834 & 20 & 0.4377 & 0.1371 & 0.9947 \\
\hline Peak Frequency & 14 & 0.3452 & 0.1527 & 0.7147 & 20 & 0.4186 & 0.2279 & 0.7807 \\
\hline \multicolumn{9}{|l|}{$1 \mathrm{mg} / \mathrm{L}$} \\
\hline Duration & 13 & 0.3777 & 0.1980 & 0.5993 & 12 & 0.4686 & 0.2082 & 0.6931 \\
\hline Peak Frequency & 13 & 0.3774 & 0.1708 & 0.7386 & 12 & 0.4288 & 0.2119 & 0.9863 \\
\hline \multicolumn{9}{|c|}{$\begin{array}{l}\text { Comparison between feeding strikes and series leading to food expulsion } \\
2 \mathrm{mg} / \mathrm{L}\end{array}$} \\
\hline Duration & 11 & 0.3776 & 0.1984 & 0.7352 & 8 & 0.5540 & 0.1434 & 0.9109 \\
\hline Peak Frequency & 11 & 0.4797 & 0.1155 & 0.9211 & 8 & 0.4870 & 0.1076 & 0.8703 \\
\hline $1 \mathrm{mg} / \mathrm{L}$ & & & & & & & & \\
\hline Duration & 8 & 0.2837 & 0.1511 & 0.4868 & 13 & 0.3913 & 0.1646 & 0.4501 \\
\hline Peak Frequency & 8 & 0.6512 & 0.4367 & 0.9484 & 13 & 0.4040 & 0.1977 & 0.8954 \\
\hline
\end{tabular}




\section{Figure Captions}

Fig. 1. Correlation of sound production with (a) feeding strikes and (b) wet weight (mg) of food in the gut of Syngnathus fuscus (black diamonds) and Syngnathus floridae (white squares).

Fig. 2. Spectrograms (top) and waveforms (bottom) of clicks produced during food intake by (a) Syngnathus fuscus and (b) Syngnathus floridae. Peak frequency is denoted by the darker shading in the spectrogram.

Fig. 3. Effects of five days of $2 \mathrm{mg} / \mathrm{L} \mathrm{O}_{2}$ on (a) food intake and (b) sound production by Syngnathus fuscus (black diamonds) and Syngnathus floridae (white squares). Means \pm SE are plotted.

Fig. 4. Behaviors associated with click production when food is not ingested by (a, c) Syngnathus fuscus and (b, d) Syngnathus floridae at (a, b) $2 \mathrm{mg} / \mathrm{L}$ and (c, d) $1 \mathrm{mg} / \mathrm{L} \mathrm{O}_{2}$. Food intake comprises the remaining behavioral coupling with sound production. Note the differences in the ranges of the behavior frequencies (y-axis).

Fig. 5. Effects of five days of $1 \mathrm{mg} / \mathrm{L} \mathrm{O}_{2}$ on (a) food intake and (b) sound production by Syngnathus fuscus (black diamonds) and Syngnathus floridae (white squares). Means \pm SE are plotted.

Fig. 6. Effects of $2 \mathrm{mg} / \mathrm{L}$ (black) versus $1 \mathrm{mg} / \mathrm{L} \mathrm{O}_{2}$ (white) on sound production by Syngnathus fuscus (diamonds) and Syngnathus floridae (squares). Means \pm SE are plotted. 

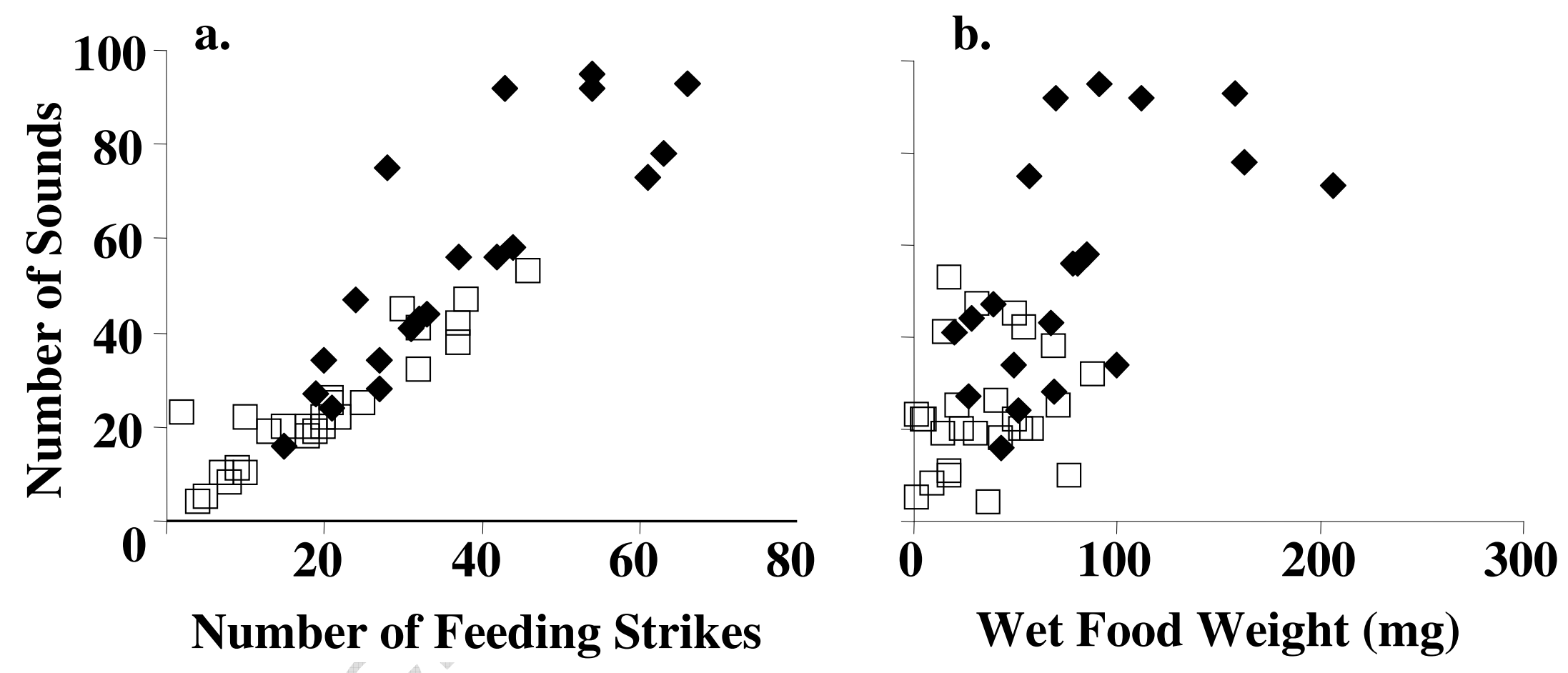
Ripley and Foran

Fig. 2

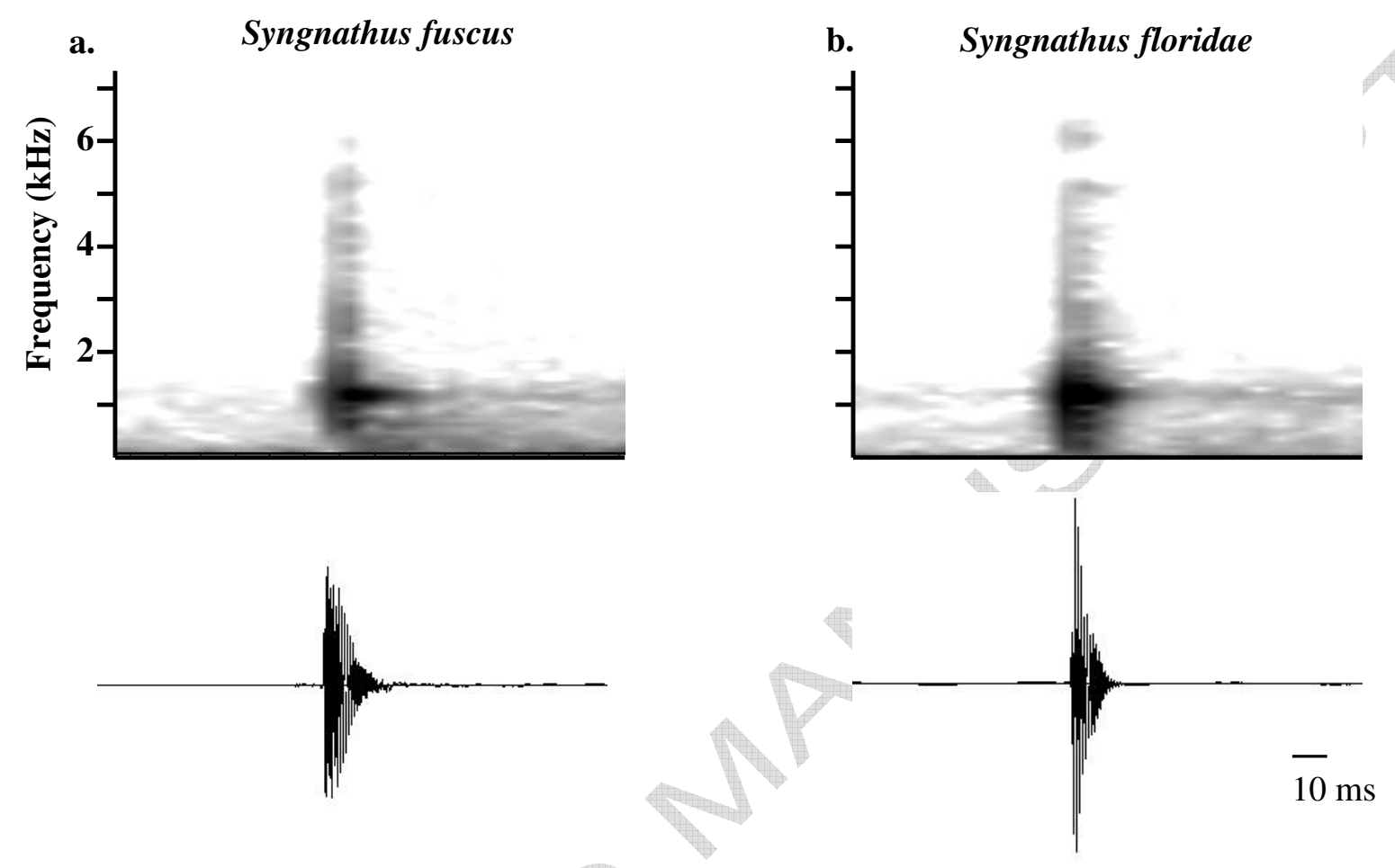


Ripley and Foran

Fig. 3
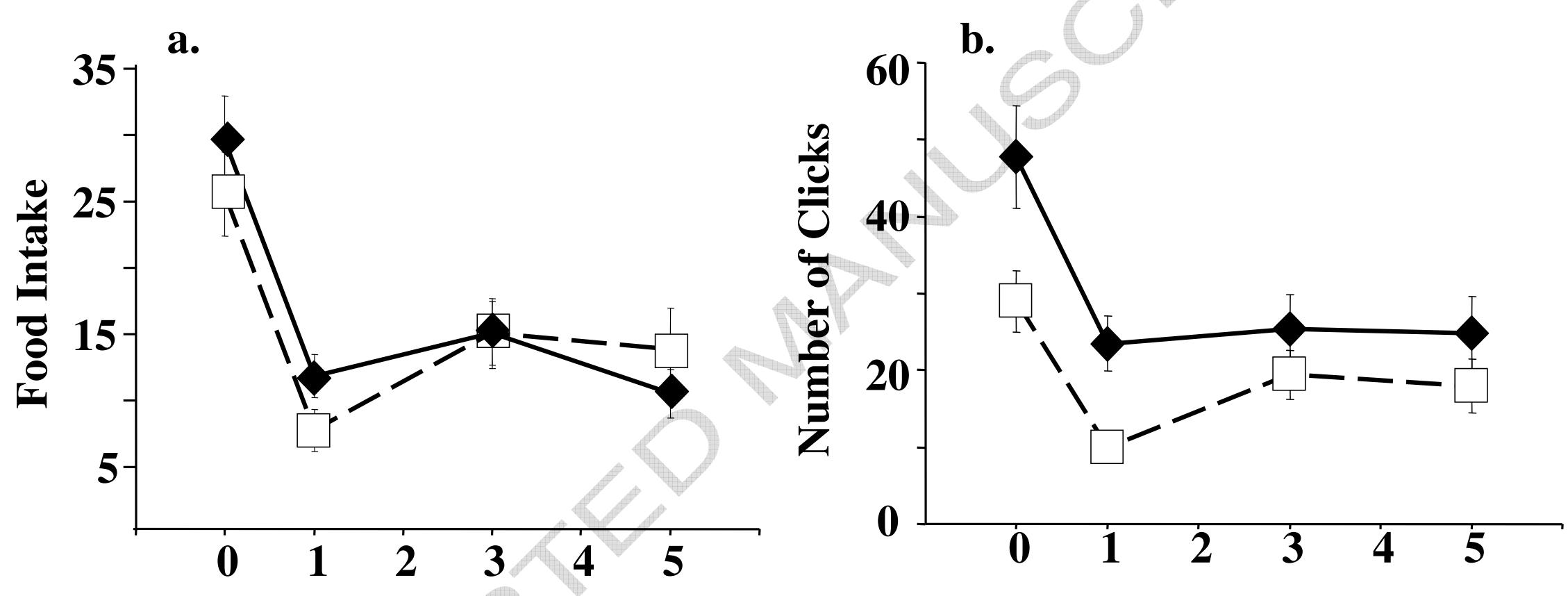

Hypoxia Exposure (Days) 
Ripley and Foran

Fig. 4
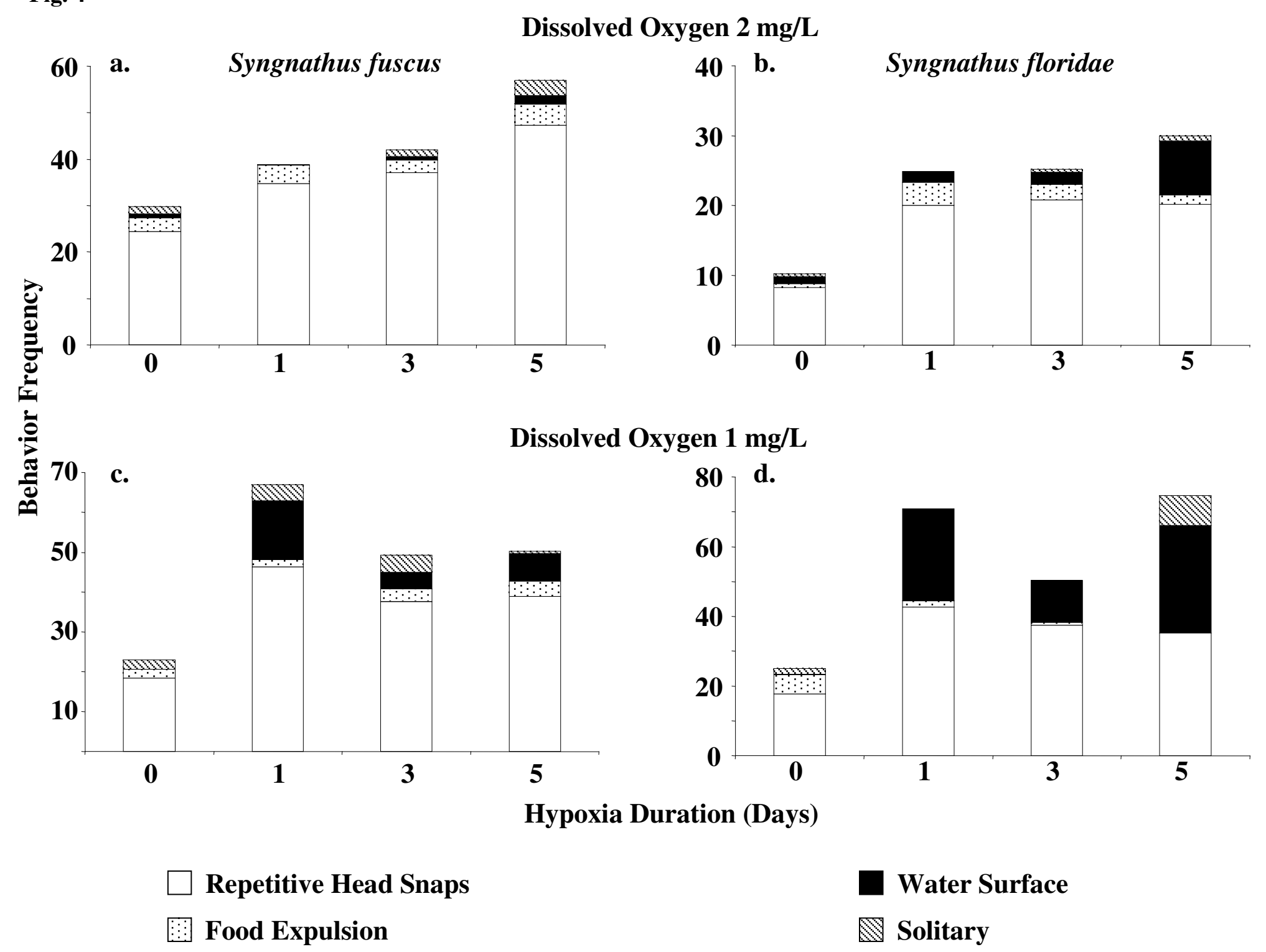

Dissolved Oxygen $1 \mathrm{mg} / \mathrm{L}$

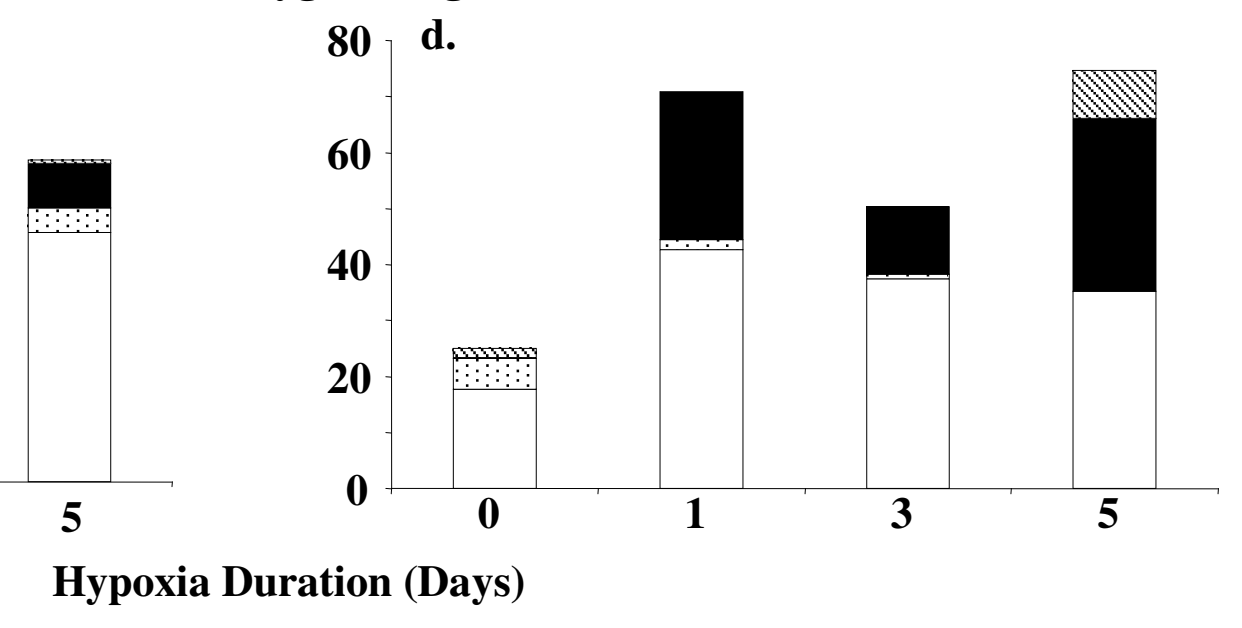

Hypoxia Duration (Days)

Water Surface

Solitary 
Ripley and Foran

Fig. 5

a.

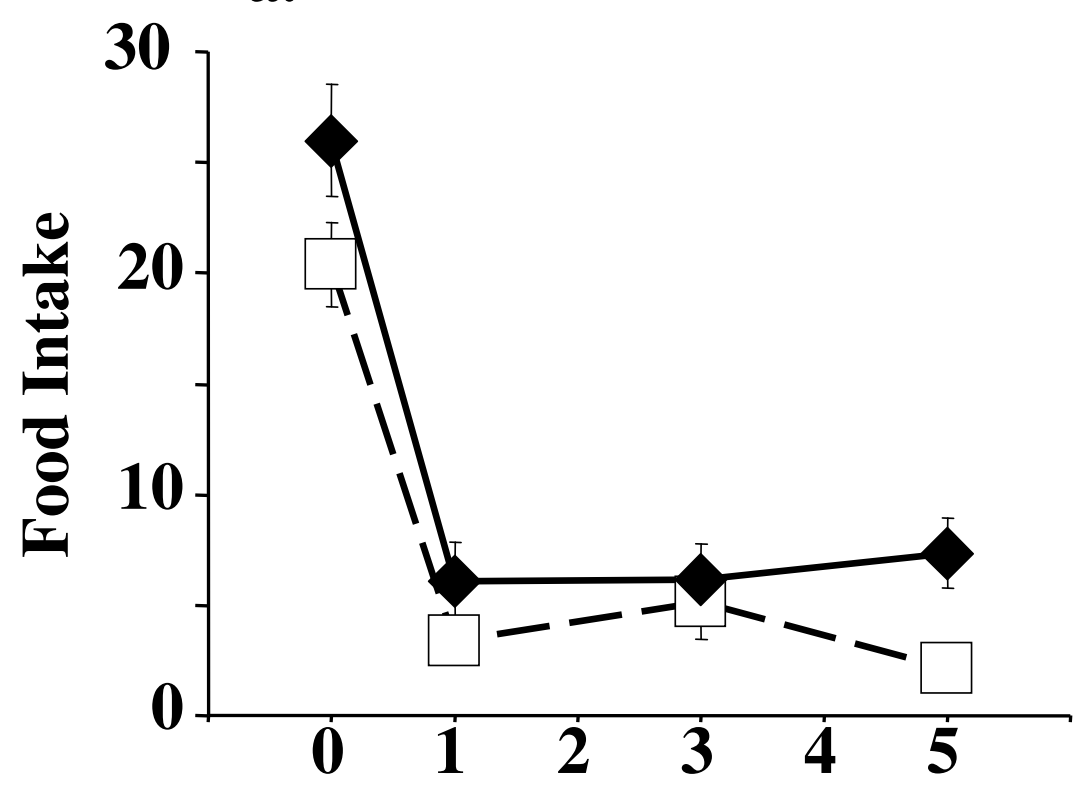

b.

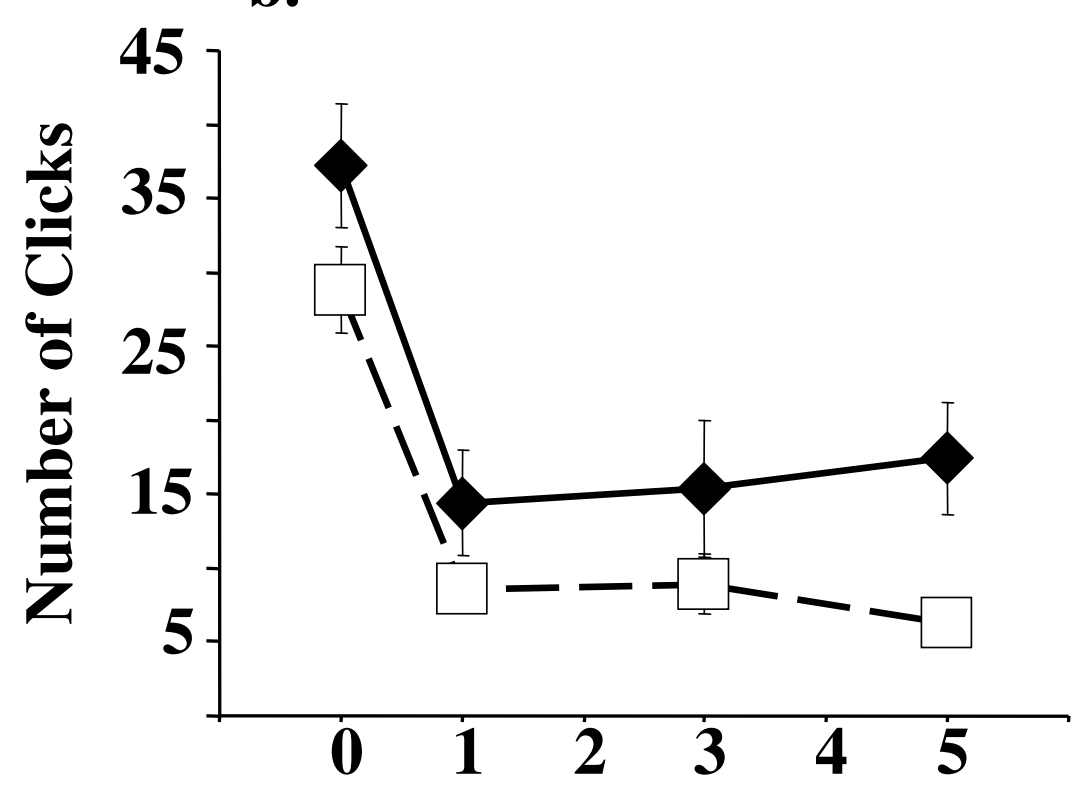

Hypoxia Exposure (Days) 
Ripley and Foran

Fig. 6
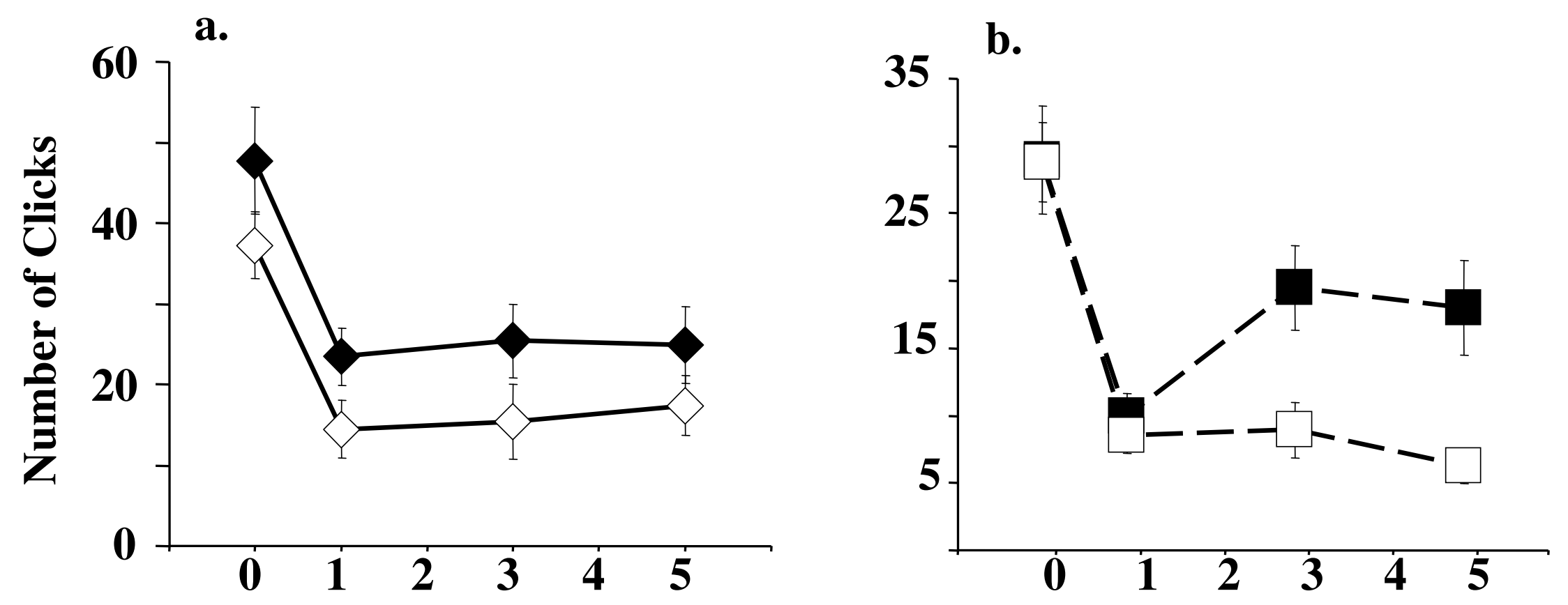

Hypoxia Exposure (Days) 